\title{
THE INFLUENCE OF THE NUMBERS OF RESIDENTS TO THE FUNCTION AND CONVENIENCE OF MOTION ON RUSUNAWA, WEST JATINEGARA, JAKARTA'S RESIDENTIAL UNITS
}

\author{
${ }^{1}$ Maria Fikka Permatasari. ${ }^{2}$ Ir. Alexander Sastrawan, M.S.P. \\ 1 Student in the Bachelor's (S-1) Study Program in Architecture \\ at Parahyangan Catholic University \\ 2 Senior lecturer in the Bachelor's (S-1) Study Program in Architecture \\ at Parahyangan Catholic University
}

\begin{abstract}
The relocation of dwellers who resided in riverbanks to flats has been implemented as part of Ciliwung river normalization project to reduce the occurrence of floods in Jakarta. In 2015, the Local Government of Capital City Jakarta had been relocated residents of Kampung Pulo to Jatinegara Rental Flats. But in fact, there were differences of population number and lifestyles between the occupants during the building design process and the occupants who were actually being relocated so there were discrepancies betwen the two communities' characteristics. Therefore, the number of occupants living in the residential flat units typically exceeds the ideal capacity that should be accommodated and can influence the function and comfort of motion of flats' residential units.
\end{abstract}

This study used qualitative descriptive method by mapping and grouping the space functions and placement of furnitures in the flats units, also comparing the placement of furnitures to human anthropometry standards, as well as researching the activities and perceptions of the occupants in the Jatinegara Barat Rental Flats units.

The aim of this study was to answer the research questions by analyzing the influence of the number of occupants to the functionality and comfort of motion at Jatinegara Rental Flats' residential units. This research is conducted hopefully to provide suggestions for improvements of flats design that are intended for dwellers who occupies the river banks area and are being relocated in order to make a better dwelling space in Jakarta to fulfill the functionality and comfort of motion at vertical housings.

The functionality and comfort of motion at the West Janitnegara Rental Flats units beside influenced by the number of occupants living in residential units, are also causes by activities of residents who are living in residential units within a certain time unit, the limited area of residential units, the placement and quantity of furnitures owned by the residents, and some restrictions about ownership and management of rental flats units.

Key Words: number of occupants, residential function, comfort in motion, West Jatinegara Rental Flats.

\section{PENGARUH JUMLAH PENGHUNI TERHADAP FUNGSI DAN KENYAMANAN GERAK PADA UNIT HUNIAN RUSUNAWA JATINEGARA BARAT JAKARTA}

\author{
${ }^{1}$ Maria Fikka Permatasari. ${ }^{2}$ Ir. Alexander Sastrawan, M.S.P. \\ ${ }^{1}$ Mahasiswa S1 Program Studi Arsitektur Universitas Katolik Parahyangan. \\ ${ }^{2}$ Dosen Pembimbing S1 Program Studi Arsitektur Universitas Katolik Parahyangan
}

\begin{abstract}
Abstrak- Perelokasian masyarakat yang bertempat tinggal di area bantaran sungai ke rumah susun dilaksanakan sebagai bagian dari program normalisasi kali Ciliwung untuk mengurangi masalah banjir di DKI Jakarta. Pada tahun 2015, Pemerintah Daerah DKI Jakarta melakukan perpindahan masyarakat Kampung Pulo ke Rusunawa
\end{abstract}

\footnotetext{
${ }^{1}$ Corresponding Author: mariafikka@gmail.com
} 
Jatinegara Barat. Namun pada kenyataannya, terjadi perbedaan populasi dan gaya hidup masyarakat antara target penghuni ketika proses mendesain bangunan dengan penghuni yang sebenarnya direlokasi sehingga terjadi ketidaksesuaian karakteristik antarpenghuni. Oleh karena itu, jumlah penghuni yang tinggal pada unit hunian rumah susun umumnya melebihi kapasitas ideal yang seharusnya ditampung sehingga mempengaruhi fungsi dan kenyamanan gerak unit hunian pada rumah susun.

Metode yang digunakan pada penelitian ini adalah metode deskriptif kualitatif dengan melakukan pemetaan dan pengelompokan fungsi ruang unit hunian dan perletakan perabot ruang-dalam unit hunian, kemudian membandingkannya dengan antopometri manusia, serta mengkaji kegiatan dan persepsi penghuni di dalam unit hunian Rusunawa Jatinegara Barat.

Tujuan dari penelitian ini adalah untuk menjawab pertanyaan penelitian dengan menganalisis pengaruh jumlah penghuni terhadap fungsi dan kenyamanan gerak unit hunian Rumah Susun Jatinegara Barat. Penelitian ini diharapkan dapat memberikan saran dalam perkembangan desain rumah susun yang ditujukan untuk masyarakat hasil relokasi bantaran sungai di Jakarta agar dapat memenuhi fungsi hunian dan kenyamanan gerak ruang hunian vertikal lebih baik.

Fungsi dan kenyamanan gerak pada unit Rusunawa Jatinegara Barat nyatanya selain dipengaruhi oleh jumlah penghuni tinggal dalam unit hunian, juga merupakan konsekuensi dari kegiatan penghuni yang tinggal pada unit hunian dalam satuan waktu tertentu, luasan unit hunian yang terbatas, perletakkan dan jumlah perabot yang dimiliki penghuni, dan batasan legalitas kepemilikan dan pengelolaan unit rusunawa.

Kata kunci: jumlah penghuni, fungsi hunian, kenyamanan gerak, Rusunawa Jatinegara Barat.

\section{PENDAHULUAN}

Rumah secara umum memiliki fungsi untuk: (1) membina kehidupan dan penghidupan keluarga dan dapat memenuhi kebutuhan biologis dan non biologis (interaksi); (2) sebagai sarana investasi yang mempunyai nilai moneter; (3) sebagai sarana berusaha sehingga penghuni dapat meningkatkan pendapatannya (4) tempat bernaung dan memenuhi kebutuhan ruang akan kegiatan bagi penghuninya, yang terdiri dari beberapa ruang pokok seperti ruang tidur, ruang belajar/kerja, ruang keluarga, ruang servis, dan ruang tamu.

Secara umum, pengertian rumah susun sederhana sewa adalah bangunan gedung bertingkat yang dibangun dalam lingkungan yang terbagi dalam bagian yang distrukturkan secara fungsional dalam arah horisontal dan vertikal dan merupakan satuan-satuan yang masing-masing digunakan secara terpisah, status penguasaannya sewa serta dibangun dengan memakai dana APBN dan/atau APBD dengan fungsi utamanya sebagai hunian.

Satuan rumah susun sederhana sewa adalah unit hunian pada rusunawa yang digunakan secara perorangan berdasarkan ketentuan persewaan. Sedangkan penghuni rusunawa didefinisikan sebagai WNI yang termasuk kelompok masyarakat berpenghasilan rendah sesuai peraturan yang berlaku yang melakukan perjanjian sewa sarusunawa dengan badan pengelola.

Pembangunan rumah susun oleh Pemerintah Daerah Provinsi DKI Jakarta dianggap sebagai solusi untuk permasalahan perumahan ibu kota yang bertujuan agar warga yang semula tinggal di kawasan bantaran sungai mendapatkan tempat tinggal yang layak huni dan lingkungan binaan yang lebih baik. Pada Agustus 2015, terjadi perelokasian warga bantaran sungai Ciliwung pada kawasan Kampung Pulo, Jakarta Timur ke Rusunawa Jatinegara Barat yang terletak di atas tanah milik Pemda DKI.

Pada awalnya Rusunawa Jatinegara Barat diperuntukan untuk masyarakat kawasan segmen pintu air Manggarai hingga jembatan Kampung Melayu. Namun kenyataannya, bangunan ini ditujukkan untuk menampung perelokasian warga kawasan Kampung Pulo yang memiliki pola gaya hidup yang berbeda dan populasi masyarakat yang lebih banyak. Hal tersebut menunjukkan bahwa adanya ketidaksesuaian antara karakteristik dan kebutuhan penghuni dengan ruang hunian yang didesain sehingga dapat mempengaruhi fungsi dan kenyamanan gerak pada unit hunian Rusunawa Jatinegara Barat. 
Penelitian ini ditujukan untuk menganalisis pengaruh jumlah penghuni terhadap fungsi dan kenyamanan gerak unit hunian Rusunawa Jatinegara Barat yang terjadi pasca huni.

\section{KAJIAN TEORI}

Pada penetian ini, pemenuhan kenyamanan gerak ruang ditinjau dari perbandingan dimensi sirkulasi penghuni dalam unit hunian rusunawa dengan standar minimal antopometri manusia. Antopometri sendiri artinya adalah pengukuran dimensi tubuh tentang sesuatu yang dipakai manusia, yang bertujuan untuk mencapai keserasian antara manusia dengan sistem kerja. Sedangkan perubahan/ fleksibilitas fungsi pada penelitian ini dilihat dari penambahan atau perubahan fungsi yang terjadi pada siang dan malam hari pada unit hunian.

\section{METODA PENELITIAN}

Penelitian ini menggunakan metode-metode deskriptif kualitatif. Metode penelitian kualitatif menurut Syaodih Nana (2007:60) adalah cara untuk mendeskripsikan dan menganalisis fenomena, peristiwa, aktivitas sosial, sikap kepercayaan, persepsi, pemikiran orang secara individual maupun kelompok. ${ }^{3}$ Sementara itu, Nawawi dan Martini (1994:73) mendefiniskan metode deskriptif sebagai metode yang melukiskan suatu keadaan objektif atau peristiwa tertentu berdasarkan fakta-fakta yang tampak atau sebagaimana mestinya yang kemudian diiringi dengan upaya pengambilan kesimpulan umum berdasarkan fakta-fakta historis tersebut.

Adapun faktor yang dapat turut serta mempengaruhi fungsi dan kenyamanan gerak adalah faktor penghuni terhadap hunian yang terdiri dari struktur keluarga, kondisi sosial, ekonomi, dan budaya; pembatasan luasan unit rusunawa yang hanya seluas 31,2 meter persegi; dan batasan legalitas berupa peraturan penghunian dan pengelolaan rusunawa.

Beberapa batasan legalitas yang dimaksud melarang penghuni untuk: (1) menyewa lebih dari satu sarusunawa; (2) mengubah prasarana, sarana dan utilitas sarusunawa yang sudah ada; (3) mengubah konstruksi bangunan sarusunawa; dan (4) meletakkan barang-barang melampaui daya dukung bangunan.

Fenomena lebihnya jumlah penghui dalam unit hunian berhubungan dengan konsep kepadatan (density) dan kesesakan (crowding) dalam ruang tertentu. Menururt Sundtrom (dalam Wrightsman \& Deaux, 1981) kepadatan adalah sejumlah manusia dalam setiap unit ruangan. Definisi lain mengenai kepadatan adalah sejumlah individu yang berada di suatu ruang atau wilayah tertentu dan lebih bersifat fisik. Baum dan Paulus (1987) menerangkan bahwa proses kepadatan dapat dirasakan sebagai kesesakan atau tidak dapat ditentukan oleh penilaian individu berdasarkan empat faktor, sebagai berikut: (1) Karakteristik seting fisik; (2) Karakteristik seting sosial; (3) Karakteristik personal; (4) Kemampuan beradaptasi

Kepadatan dapat dibedakan ke dalam beberapa kategori. Holahan (1982) menggolongkan kepadatan menjadi 2 kategori, yaitu kepadatan spasial (spatial density) yang terjadi bila besar atau luas ruangan diubah menjadi lebih kecil atau sempit sedangkan jumlah individu tetap, sehingga didiapatkan kepadatan meningkat sejalan menurunnya besar ruang, dan kepadatan sosial (social density) yang terjadi bila jumlah individu ditambah tanpa diiringi dengan penambahan luas atau besar ruangan.

Kenyamanan gerak ruang dan perubahan/ fleksibilitas fungsi yang terjadi pada unit hunian merupakan bentuk dari penyesuaian diri atau adaptabilitas penghuni pada unit hunian akibat kepadatan (density) dan kesesakan (crowding) pada ruang yang diaplikasikan melalui 
pengelompokan komposisi dan organisasi adaptasi ruang yang dilakukan untuk merubah tempat tinggal menjadi lebih layak.

\section{ANALISA}

\subsection{UNIT HUNIAN RUSUNAWA JATINEGARA BARAT}

Rusunawa Jatinegara Barat terdiri dari dua tower utama yang terdiri dari 16 lantai dan masing-masing lantai terdiri dari 19 unit (untuk tower A) dan 18 unit (untuk tower B). Fasilitas dalam unit hunian rusunawa ukuran untuk tiap unit sebesar 5,8 x 5,2 meter, yakni terdiri dari: (1) ruang keluarga / makan / tamu dan ditambah fasilitas dapur dengan ukuran 3,25m x 4,15m; (2) 2 kamar tidur dengan ukuran masing-masing 2,125m x 2,55m (3) Kamar mandi dengan ukuran 1,05m x 2,8m; (4) Balkon luar sebagai ruang jemur dengan ukuran 2,125m x 0,95m; (5) teras luar untuk kor koridor dengan lebar 1,5 meter.

Penelitian mengambil 10 sampel unit rusunawa yang didata secara random sampling untuk menunjukan ruang dalam hunian unit rusunawa.

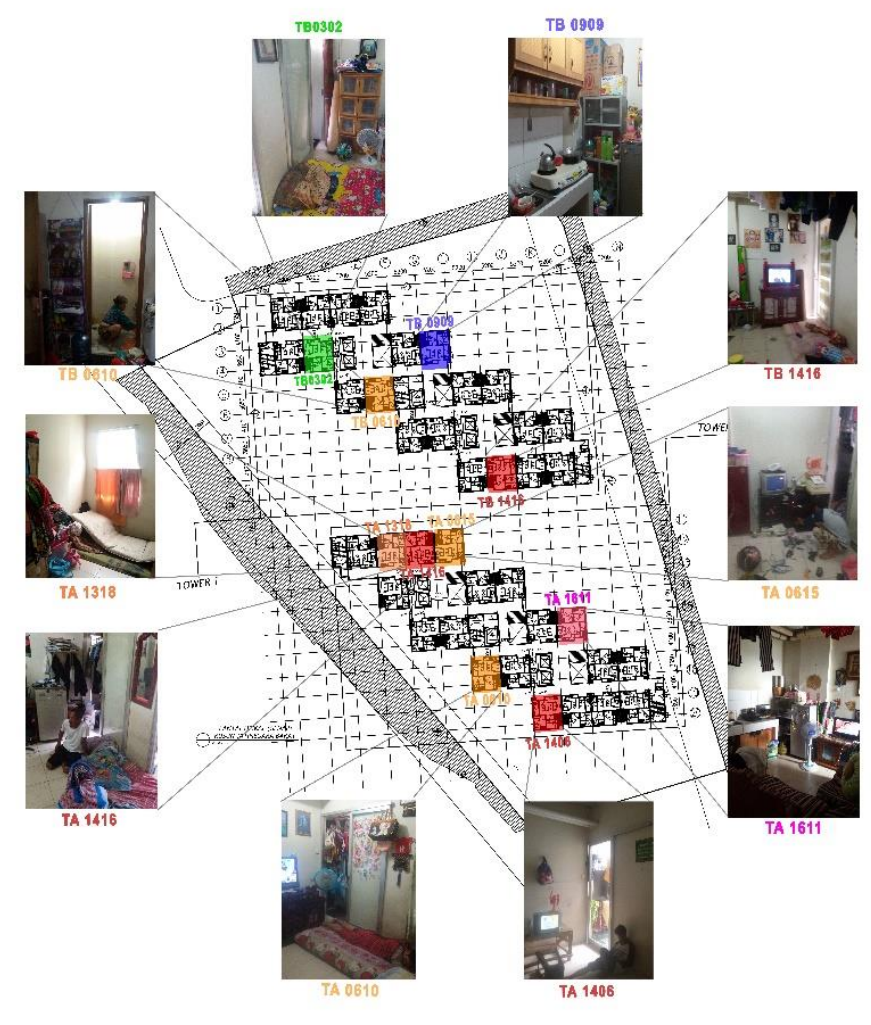

Figur 1. Lokasi Pengambilan Sampel Unit Hunian Rusunawa Jatinegara Barat.

Sepuluh unit sampel yang akan dianalisis kenyamanan gerak \& perubahan/fleksibilitas fungsi, antara lain sebagai berikut:

(1) TB 0610, terdiri dari 4 orang

(2) TB 1416, terdiri dari 4 orang.

(3) TA 0610, terdiri dari 4 orang.

(4) TA 1318, terdiri dari 6 orang

(5) TA 1406, terdiri dari 6 orang

(6) TA 1611, terdiri dari 6 orang

(7) TB 0302, terdiri dari 7 orang

(8) TB 0909, terdiri dari 7 orang

(9) TA 0615, terdiri dari 8 orang

(10) TA 1416 , terdiri dari 8 orang

Kenyamanan gerak dan perubahan / fleksibilitas fungsi

pada unit hunian Rusunawa Jatinegara Barat ditentukan oleh kegiatan penghuni dalam unit hunian yang menentukan jumlah penghuni yang tinggal dalam unit huniannya dalam periode waktu tertentu.

Dari grafik di bawah ini diketahui bahwa jam sibuk (peak hour) penghuni yang tinggal di dalam unit hunian pada malam hari hingga subuh (jam 9 PM - 4 AM) sehingga jumlah penghuni yang berkegiatan dalam unit rusunawa mencapai jumlah penghuni maksimal. Sehingga jumlah penghuni dalam unit rusunawa mencapai jumlah maksimal. Ketika jumlah penghuni mencapai jumlah maksimal, tercipta kepadatan (density) dan kesesakan (crowding) ruang yang mendorong terjadinya ketidaknyamanan gerak dan adaptasi yang dilakukan 
penghuni yang bersifat perubahan / fleksibilitas ruang yang umumnya terjadi pada ruang ruang di unit hunian, khususnya di ruang keluarga/ tamu/ makan yang luasan terbesar dalam unit hunian dan memiliki fungsi yang fleksibel.

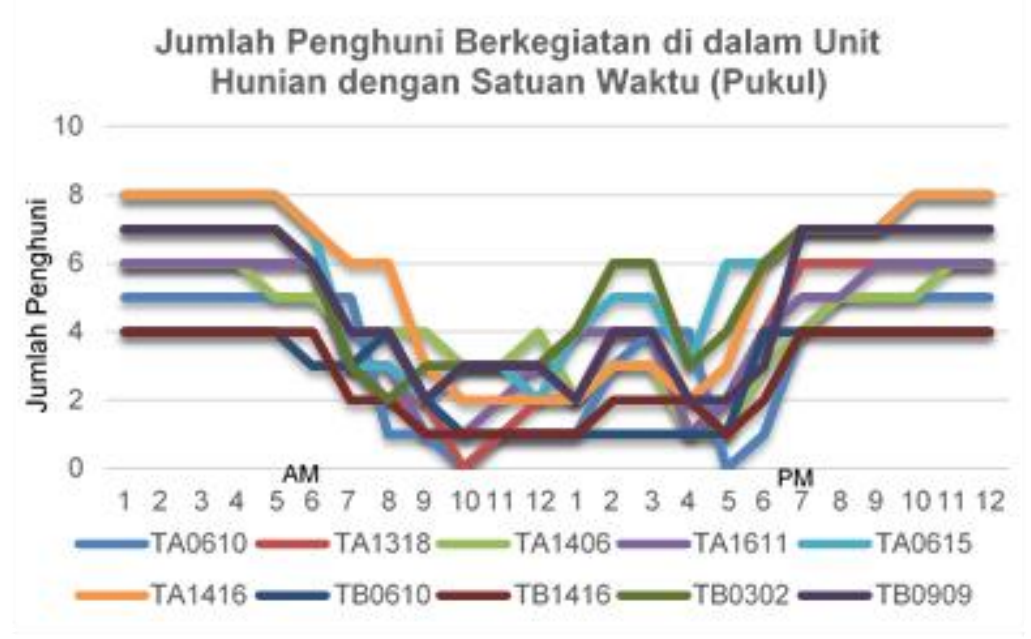

Figur 2. Intensitas Kegiatan Penghuni di Dalam Unit Hunian Menurut Waktu

Pada jam efektif seperti siang dan sore hari, jumlah penghuni dalam unit hunian rusunawa bersifat fluktuatif yang disebabkan oleh banyaknya aktivitas penghuni yang dilakukan di luar unit hunian. Selian itu juga disebabkan oleh perbedaan struktur keluarga masing-masing unit hunian, status penghuni di dalam keluarga tersebut, kegiatan di dalam dan di luar unit rusunawa, umur, serta latar belakang pekerjaan penghuni yang bervarariatif.

\subsubsection{UNIT TB 0610}

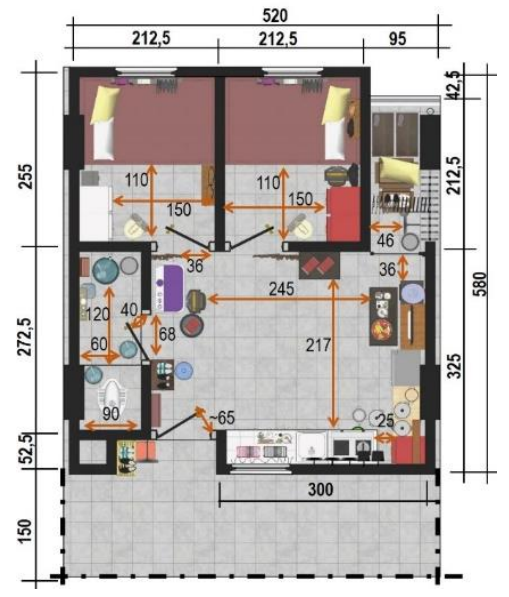

Figur 3. Dimensi sirkulasi unit TB0610

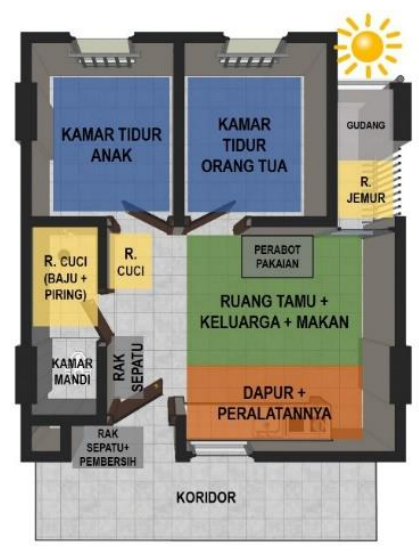

Figur 4. Zoning Unit TB 0610 ketika siang hari

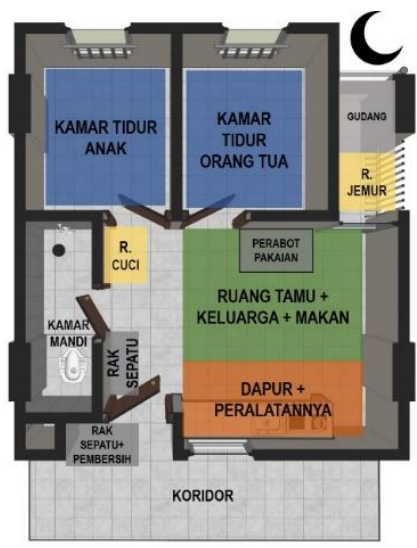

Figur 5. Zoning Unit TB 0610 ketika malam hari

Penghuni TB 0610 dengan struktur keluarga yang terdiri dari 4 orang (ayah, ibu, dan 2 anak laki-laki.) melakukan adaptasi terhadap unit huniannya dengan melakukan perubahan atau fleksibilitas fungsi ruang pada siang dan malam hari yang dilakukan oleh penghuni untuk memenuhi kebutuhan ruang hunian, antara lain: (1) Penambahan fungsi gudang pada ruang jemur; (2) Penambahan fungsi ruang cuci pada kamar mandi dan sekitarnya; (3) Perletakan perabot tambahan pada daerah entrance unit hunian dan pada ruang keluarga / tamu / makan. 
Adaptasi pada unit hunian TB 0610 juga dilakukan dengan menata layout ruang-dalam unit untuk mendapat luasan efektif, kemudian dibandingkan dengan standar antropometri manusia untuk menentukan kenyamanan gerak dalam unit hunian tersebut. Ruang yang tidak memenuhi kenyamanan gerak dalam unit hunian TB 0610, antara lain: (1) Pergerakan sirkulasi dari ruang keluarga menuju ke kamar tidur anak karena adanya perabot untuk fungsi ruang cuci yang terletak di entrance kamar tidur; (2)Ruang efektif pada kamar mandi yang tidak mencukupi untuk fungsi kamar mandi dan ruang cuci yang terjadi. (3) Pergerakan pada ruang jemur karena banyaknya perabot yang diletakkan untuk fungsi gudang dan tinggi gantungan jemuran yang bertabrakan dengan skala manusia yang tidak memenuhi standar antopometri manusia.

\subsubsection{UNIT TB 1416}

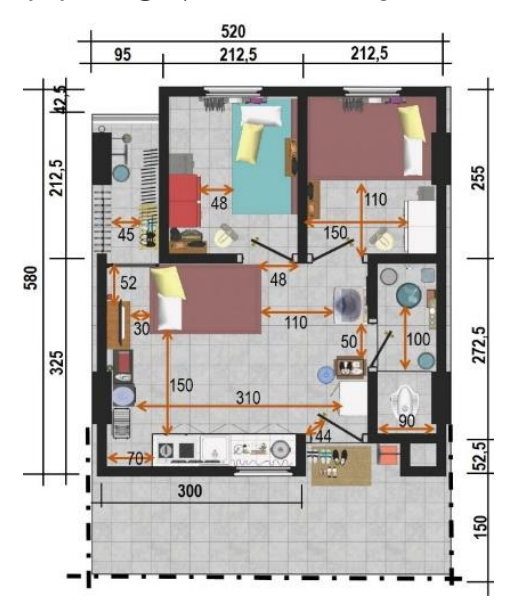

Figur 6. Dimensi sirkulasi unit TB1416

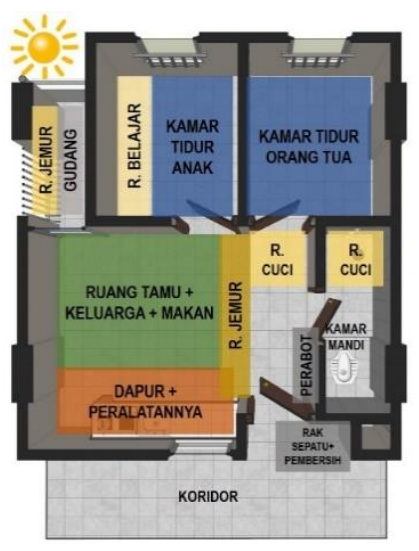

Figur 7. Zoning Unit TB 1416 ketika siang hari

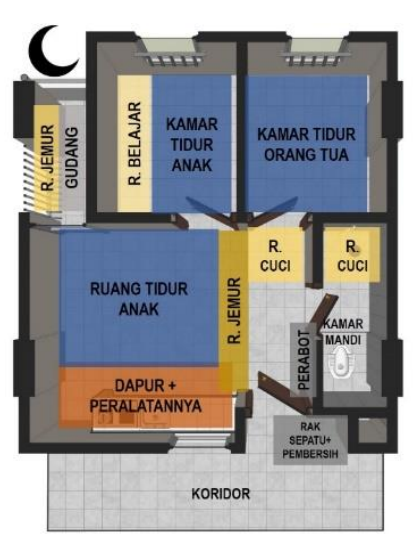

Figur 8. Zoning Unit TB 1416 ketika malam hari

Penghuni TB 1416 dengan struktur keluarga yang terdiri dari 4 orang (ayah, ibu, dan 1 anak laki-laki, dan 1 anak perempuan) melakukan dengan melakukan perubahan atau fleksibilitas fungsi ruang pada siang dan malam hari yang dilakukan oleh penghuni untuk memenuhi kebutuhan ruang hunian, antara lain: (1) Perubahan fungsi ruang makan / keluarga / makan menjadi ruang tidur tambahan; (2) Penambahan fungsi ruang jemur pada langit-langit ruang keluarga; (3) Penambahan fungsi gudang pada ruang jemur; (4) Penambahan fungsi ruang cuci pada kamar mandi dan sekitarnya;

Adaptasi pada unit hunian TB 1416 juga dilakukan dengan menata layout ruang-dalam unit untuk mendapat luasan efektif, kemudian dibandingkan dengan standar antropometri manusia untuk menentukan kenyamanan gerak dalam unit hunian tersebut. Ruang yang tidak memenuhi kenyamanan gerak dalam unit hunian TB 1416, antara lain: (1) Pergerakan sirkulasi dari ruang keluarga menuju ke kamar tidur anak dan ruang jemur dikarenakan penambahan fungsi ruang tidur pada ruang keluarga; (2) Skala ruang ketinggian manusia pada langit-langit ruang keluarga akibat penambahan fungsi jemur yang terbentuk; (3) Pergerakan pada kamar tidur anak, kamar mandi, dan ruang jemur karena perletakan perabot yang tidak efektif. Selain itu, tinggi gantungan jemuran (pada ruang jemur) bertabrakan dengan skala ruang manusia.

\subsubsection{UNIT TA 0610}




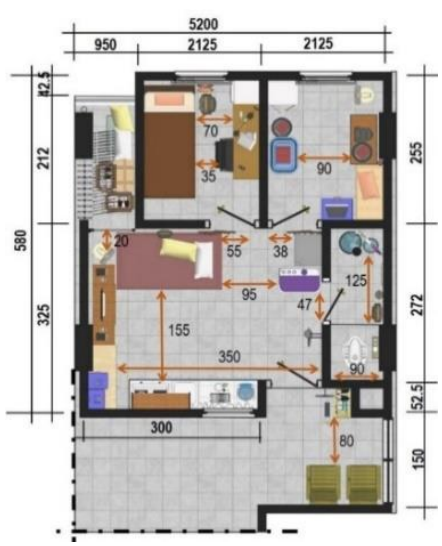

Figur 9. Dimensi sirkulasi unit TA0610

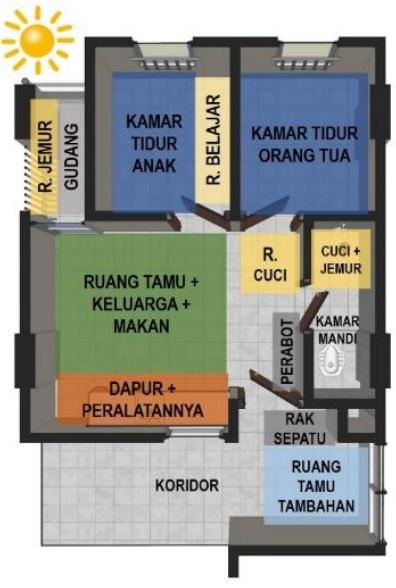

Figur 10. Zoning Unit TA 0610 ketika siang hari

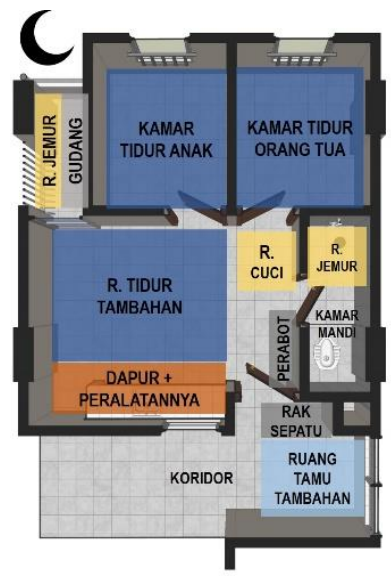

Figur 11. Zoning Unit TA 0610 ketika malam hari

Penghuni TA 0610 dengan struktur keluarga yang terdiri dari 5 orang (ayah, ibu, dan 3 anak perempuan) melakukan adaptasi dengan melakukan perubahan atau fleksibilitas fungsi ruang pada siang dan malam hari yang dilakukan oleh penghuni untuk memenuhi kebutuhan ruang hunian, antara lain: (1) Perubahan fungsi ruang makan / keluarga / makan menjadi ruang tidur tambahan; (2) Penambahan fungsi ruang tamu tambahan pada koridor luar; (3) Penambahan fungsi gudang pada ruang jemur; (4) Penambahan fungsi ruang jemur dan cuci pada kamar mandi dan sekitarnya; (5) Perletakan perabot tambahan pada daerah entrance unit hunian.

Adaptasi pada unit hunian TA 0610 juga dilakukan dengan menata layout ruang-dalam unit untuk mendapat luasan efektif, kemudian dibandingkan dengan standar antropometri manusia untuk menentukan kenyamanan gerak dalam unit hunian tersebut. Ruang yang tidak memenuhi kenyamanan gerak dalam unit hunian TA 0610, antara lain: (1) Pergerakan sirkulasi dari ruang keluarga menuju ke kamar tidur anak dan orang tua, ruang jemur, dan kamar mandi karena perletakan perabot yang bersifat menambah fungsi pada ruang tertentu (seperti ruang tidur pada ruang keluarga); (2) Pergerakan pada kamar tidur anak, kamar mandi, dan ruang jemur karena perletakan perabot yang tidak efektif. Selain itu, tinggi gantungan jemuran (pada ruang jemur) bertabrakan dengan skala ruang manusia.

\subsubsection{UNIT TA 1318}

Penghuni TA 1318 dengan struktur keluarga yang terdiri dari 6 orang (ayah, ibu, 1 anak lelaki, 2 anak perempuan, dan 1 cucu) melakukan dengan melakukan perubahan atau fleksibilitas fungsi ruang pada siang dan malam hari yang dilakukan oleh penghuni untuk memenuhi kebutuhan ruang hunian, antara lain: (1) Perubahan fungsi ruang makan / keluarga / makan menjadi ruang tidur tambahan; (2) Penambahan fungsi produksi makanan pada ruang dapur; (3) Penambahan fungsi gudang pada ruang jemur; (4) Penambahan fungsi ruang jemur dan cuci pada kamar mandi dan sekitarnya; (5) Perletakan perabot dapur pada entrance kamar anak (yang masih dalam teritori ruang keluarga/ makan/ tamu); 


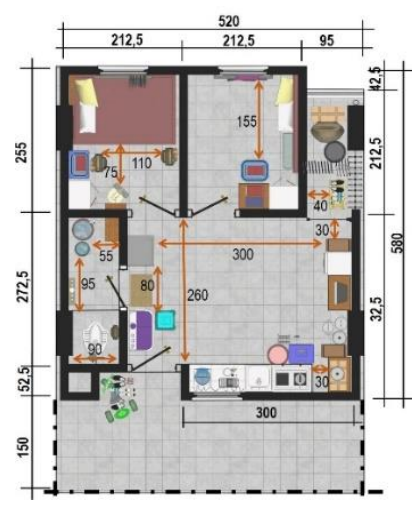

Figur 12. Dimensi sirkulasi unit TA1318

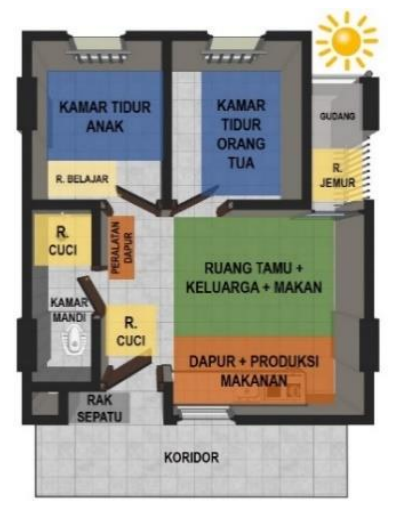

Figur 13. Zoning Unit TA 1318 ketika siang hari

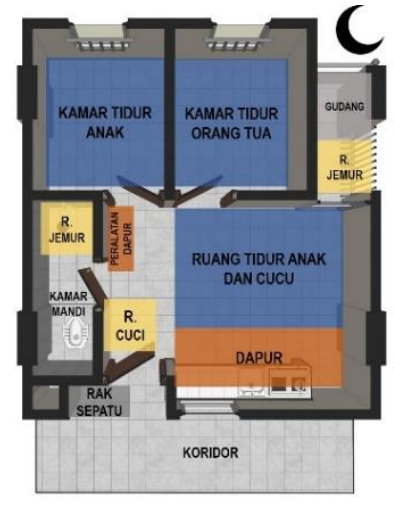

Figur 14. Zoning Unit TA 1318 ketika malam hari

Adaptasi pada unit hunian TA 1318 juga dilakukan dengan menata layout ruang-dalam unit untuk mendapat luasan efektif, kemudian dibandingkan dengan standar antropometri manusia untuk menentukan kenyamanan gerak dalam unit hunian tersebut. Ruang yang tidak memenuhi kenyamanan gerak dalam unit hunian TA 1318, antara lain: (1) Ruang efektif pada kamar mandi yang tidak mencukupi untuk fungsi kamar mandi dan ruang cuci yang terjadi; (2) Pergerakan pada ruang jemur yang minim karena banyaknya perabot yang diletakkan. Selain itu, tinggi gantungan jemuran yang bertabrakan dengan skala tinggi manusia yang tidak menimbulkan ketidaknyamanan skala ruang manusia.

\subsubsection{UNIT TA 1406}

Pada unit TA 1406, penggunan perabot yang minim menyebabkan ruang gerak manusia pada cenderung lebih luas dan meminimalisir perubahan/ fleksibilitas fungsi.

Penghuni TA1406 dengan struktur keluarga yang terdiri dari 6 orang (ayah, ibu, nenek, dan 3 anak laki-laki) melakukan adaptasi dengan melakukan perubahan atau fleksibilitas fungsi ruang pada siang dan malam hari yang dilakukan oleh penghuni untuk memenuhi kebutuhan ruang hunian, antara lain: (1) Perubahan fungsi ruang makan / keluarga / makan menjadi ruang tidur tambahan; (2) Penambahan fungsi ruang cuci pada kamar mandi dan sekitarnya;

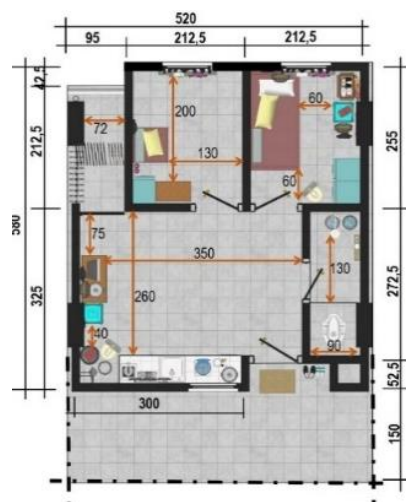

Figur 15. Dimensi sirkulasi unit TA1406

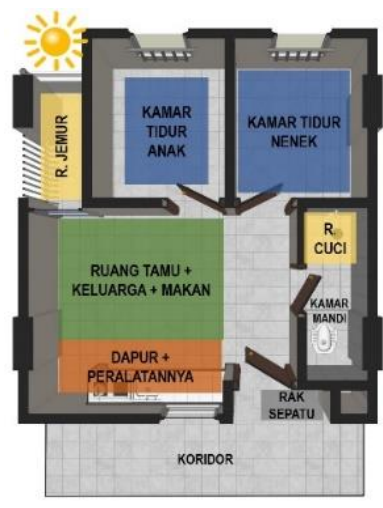

Figur 16. Zoning Unit TA 1406 ketika siang hari

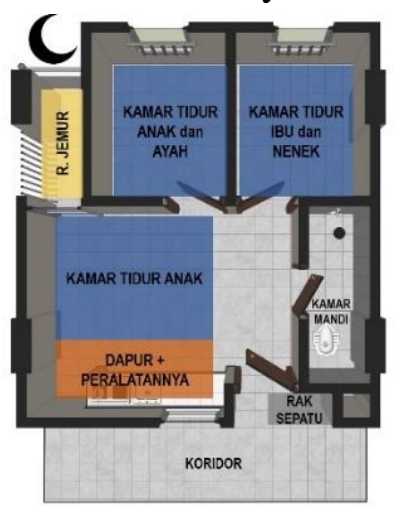

Figur 17. Zoning Unit TA 1406 ketika malam hari

Adaptasi pada unit hunian TA 1406 juga dilakukan dengan menata layout ruang-dalam unit untuk mendapat luasan efektif, kemudian dibandingkan dengan standar antropometri manusia untuk menentukan kenyamanan gerak dalam unit hunian tersebut. Ruang yang tidak 
memenuhi kenyamanan gerak dalam unit hunian TA 1406, antara lain: (1) Pergerakan sirkulasi pada kamar tidur utama yang disebabkan tidak memenuhi standar antopometri manusia minimal yang ditentukan; (2) Ruang efektif pada kamar mandi yang tidak mencukupi untuk fungsi kamar mandi dan ruang cuci yang terjadi; (3) Skala ruang manusia yang tidak nyaman pada ruang jemur karena tinggi gantungan jemuran yang bertabrakan dengan skala ketinggian manusia.

\subsubsection{UNIT TA 1611}

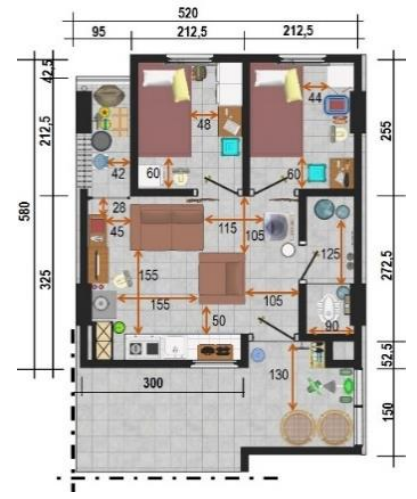

Figur 18. Dimensi sirkulasi unit TA 1611

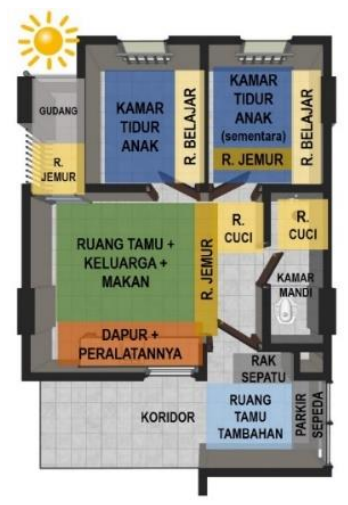

Figur 19. Zoning Unit TA 1611 ketika siang hari

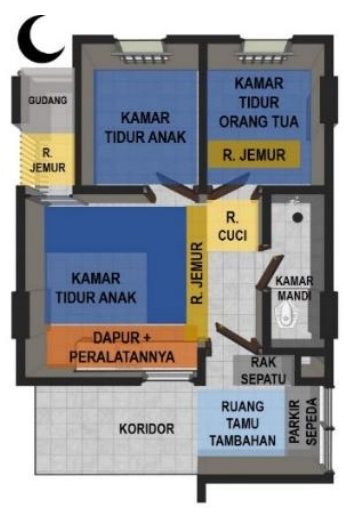

Figur 20. Zoning Unit TA 1611 ketika malam hari

Penghuni dengan struktur keluarga yang terdiri dari 6 orang (ayah, ibu, dan 4 anak perempuan) melakukan adaptasi dengan melakukan perubahan atau fleksibilitas fungsi ruang pada siang dan malam hari yang dilakukan oleh penghuni untuk memenuhi kebutuhan ruang hunian, antara lain: (1) Perubahan fungsi ruang makan / keluarga / makan menjadi ruang tidur tambahan; (2) Penambahan fungsi ruang cuci pada kamar mandi dan sekitarnya; (3) Penambahan fungsi gudang pada ruang jemur; (4) Penambahan fungsi ruang jemur pada kamar tidur utama dan ruang keluarga; (5) Penambahan fungsi ruang tamu tambahan dan parkir pada koridor luar.

Adaptasi pada unit hunian TA 1611 juga dilakukan dengan menata layout ruang-dalam unit untuk mendapat luasan efektif, kemudian dibandingkan dengan standar antropometri manusia untuk menentukan kenyamanan gerak dalam unit hunian tersebut. Ruang yang tidak memenuhi kenyamanan gerak dalam unit hunian TA 1611, antara lain: (1) Skala ruang manusia yang tidak nyaman pada ruang keluarga dan kamar tidur utama karena adanya penambahan fungsi ruang jemur yang disebabkan tinggi gantungan jemuran bertabrakan dengan skala ketinggian manusia; (2) Sirkulasi pada ruang keluarga, kedua kamar tidur, dan kamar mandi, dan ruang jemur tidak memenuhi standar antopometri manusia yang artinya tidak nyaman gerak. Selain itu, skala ruang ketinggian manusia pada ruang jemur tidak nyaman. 


\subsubsection{UNIT TB 0302}

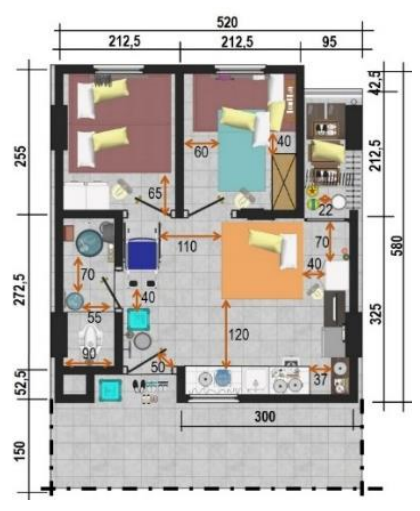

Figur 21. Dimensi sirkulasi unit TB 0302

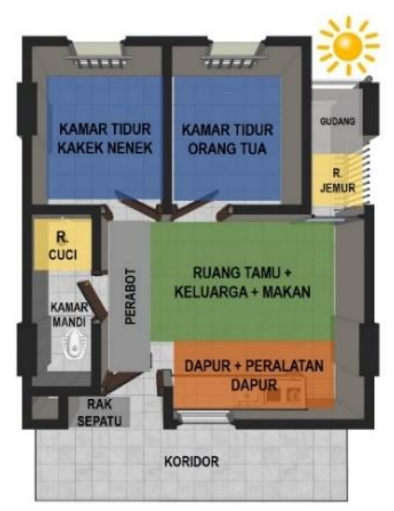

Figur 22. Zoning Unit TB 0302 ketika siang hari

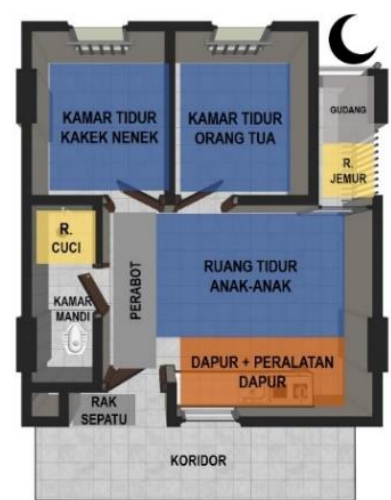

Figur 23. Zoning Unit TB 0302 ketika malam hari

Penghuni TB 0302 dengan struktur keluarga yang terdiri dari 7 orang (kakek, nenek, ayah, ibu, 1 anak lelaki, 1 anak perempuan) melakukan adaptasi dengan melakukan perubahan atau fleksibilitas fungsi ruang pada siang dan malam hari yang dilakukan oleh penghuni untuk memenuhi kebutuhan ruang hunian, antara lain: (1) Perubahan fungsi ruang makan / keluarga / makan menjadi ruang tidur tambahan; (2) Penambahan fungsi gudang pada ruang jemur; (3) Penambahan fungsi ruang cuci pada kamar mandi dan sekitarnya; (4) Perletakan Perabot tambahan pada daerah entrance unit hunian dan bagian tepi pada ruang keluarga.

Adaptasi pada unit hunian TB 0302 juga dilakukan dengan menata layout ruang-dalam unit untuk mendapat luasan efektif, kemudian dibandingkan dengan standar antropometri manusia untuk menentukan kenyamanan gerak dalam unit hunian tersebut. Ruang yang tidak memenuhi kenyamanan gerak dalam unit hunian TB 0302, antara lain: (1) Pergerakan sirkulasi pada ruang keluarga / tamu / makan, kamar tidur orang tua dan kamar mandi dan ruang jemur yang tidak memenuhi antopometri minimal manusia karena perletakan pearabot yang tidak efektif atau banyaknya perabot yang dimiliki penghuni. (2) Sirkulasi dari ruang keluarga menuju kamar mandi dan kamar tidur tidak memenuhi antopometri minimal, dan adaptasi dilakukan dengan melakukan penggeseran perabot dari waktu ke waktu.

\subsubsection{UNIT TB 0909}

Penghuni TB 0909 dengan struktur keluarga yang terdiri dari 7 orang (ayah, ibu, 3 anak lelaki, 1 anak perempuan, 1 menantu) melakukan adaptasi dengan melakukan perubahan atau fleksibilitas fungsi ruang pada siang dan malam hari yang dilakukan oleh penghuni untuk memenuhi kebutuhan ruang hunian, antara lain:: (1) Perubahan kamar tidur anak menjadi ruang kerja jahit (untuk ayah); (2) Perubahan fungsi ruang makan / keluarga / makan menjadi ruang tidur tambahan; (3) Penambahan fungsi ruang jemur pada langit-langit ruang keluarga; (4) Penambahan fungsi ruang tamu tambahan pada koridor; (5) Penambahan fungsi gudang pada ruang jemur; (6) Penambahan fungsi ruang cuci dan jemur pada kamar mandi dan sekitarnya. 


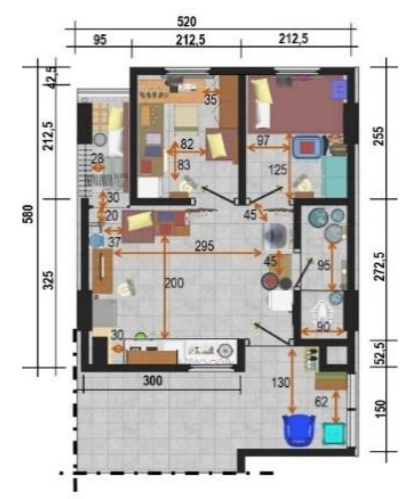

Figur 24. Dimensi sirkulasi unit TB 0909

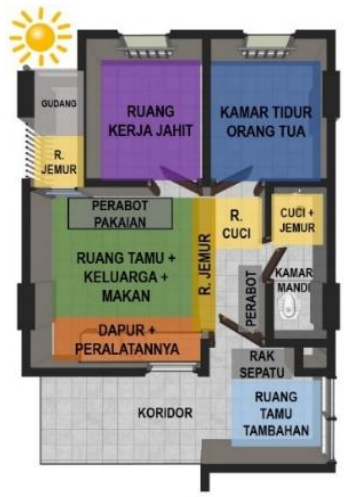

Figur 25. Zoning Unit TB 0909 ketika siang hari

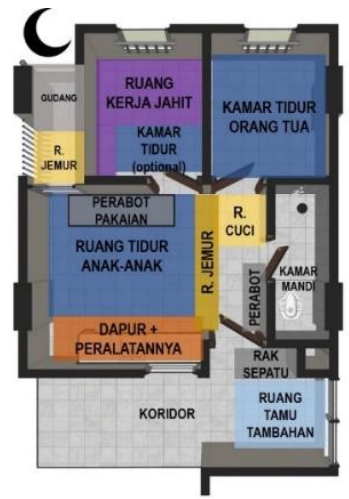

Figur 26. Zoning Unit TB 0909 ketika malam hari

Adaptasi pada unit hunian TB 0909 juga dilakukan dengan menata layout ruang-dalam unit untuk mendapat luasan efektif, kemudian dibandingkan dengan standar antropometri manusia untuk menentukan kenyamanan gerak dalam unit hunian tersebut. Ruang yang tidak memenuhi kenyamanan gerak dalam unit hunian TB 0909, antara lain: (1) Skala ketinggian ruang yang tidak nyaman pada ruang keluarga karena adanya penambahan fungsi ruang jemur pada langit-langitnya; (2) Pergerakan sirkulasi yang kurang nyaman pada entrance kamar tidur, pada ruang jahit dan kamar mandi, serta pada ruang keluarga / makan / tamu dan ruang jemur yang tidak memenuhi antopometri minimal manusia karena perletakan pearabot yang tidak efektif atau banyaknya perabot yang dimiliki penghuni.

\subsubsection{UNIT TA 0615}

Penghuni TA 0615 dengan struktur keluarga yang terdiri dari 8 orang (ayah, ibu, 1 anak lelaki, 4 anak perempuan, 1 menantu) melakukan dengan melakukan perubahan atau fleksibilitas fungsi ruang pada siang dan malam hari yang dilakukan oleh penghuni untuk memenuhi kebutuhan ruang hunian, antara lain: (1) Perubahan ruang keluarga menjadi ruang kerja mekanik (siang hari) dan perubahan dapur menjadi ruang produksi makanan (siang hari); (2) Perubahan fungsi ruang keluarga menjadi ruang tidur tambahan pada malam hari; (3) Penambahan fungsi ruang jemur pada langit-langit ruang keluarga; (4) Penambahan fungsi ruang tamu tambahan pada koridor; (5) Penambahan fungsi gudang pada ruang jemur; (6) Penambahan fungsi ruang cuci pada kamar mandi dan sekitarnya.

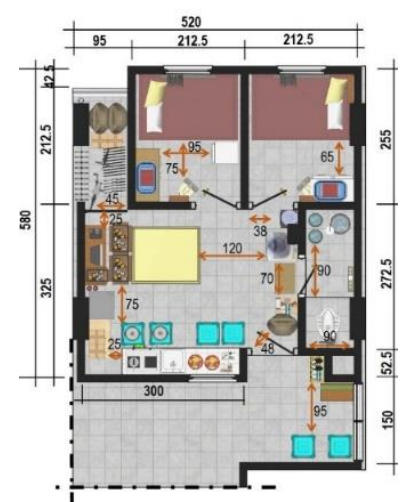

Figur 27. Dimensi sirkulasi unit TA 0615

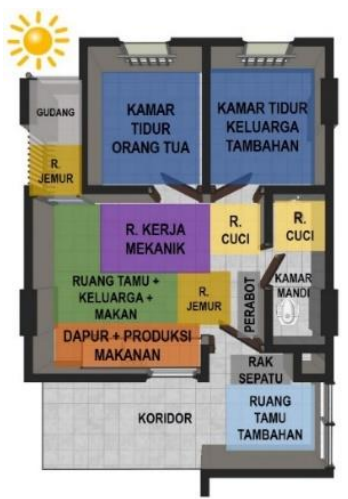

Figur 28. Zoning Unit TA 0615 ketika siang hari

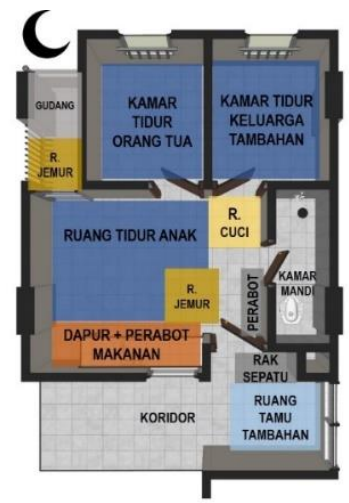

Figur 29. Zoning Unit TA 0615 ketika malam hari 
Adaptasi pada unit hunian TA 0615 juga dilakukan dengan menata layout ruang-dalam unit untuk mendapat luasan efektif, kemudian dibandingkan dengan standar antropometri manusia untuk menentukan kenyamanan gerak dalam unit hunian tersebut. Ruang yang tidak memenuhi kenyamanan gerak dalam unit hunian TA 0615, antara lain: (1) Pergerakan sirkulasi yang kurang nyaman pada entrance unit hunian dan kamar mandi, serta sirkulasi pada ruang keluarga menuju kamar tidur keluarga sekunder; (2) Kurang nyamannya pergerakan pada ruang jemur dan pada ruang keluarga akibat penambahan ruang jemur dikarenakan tinggi gantungan jemuran yang bertabrakan dengan skala manusia.

\subsubsection{UNIT TA 1416}

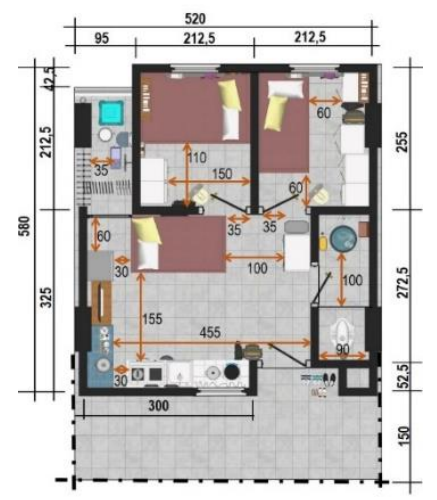

Figur 30. Dimensi sirkulasi unit TA 1416

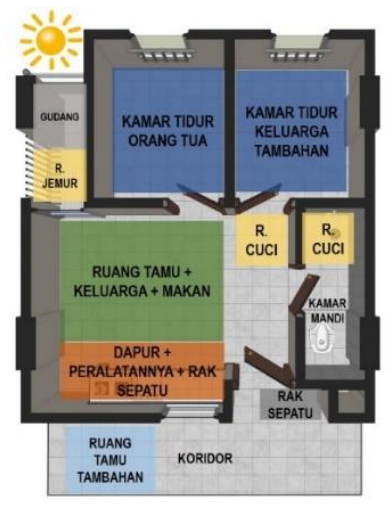

Figur 31. Zoning Unit TA 1416 ketika siang hari

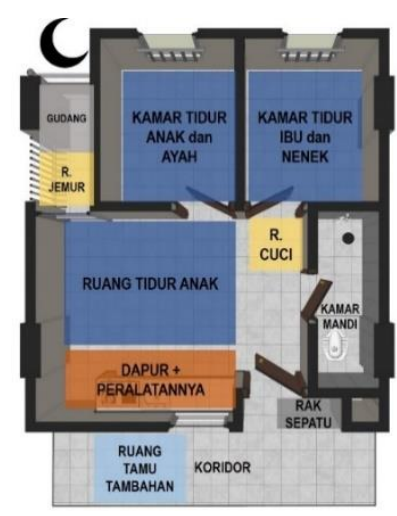

Figur 32. Zoning Unit TA 1416 ketika malam hari

Penghuni dengan struktur keluarga yang terdiri dari 8 orang (ayah, ibu, 1 anak lelaki, 4 anak perempuan, 1 menantu) melakukan adaptasi dengan melakukan perubahan atau fleksibilitas fungsi ruang pada siang dan malam hari yang dilakukan oleh penghuni untuk memenuhi kebutuhan ruang hunian, antara lain: (1) Perubahan fungsi ruang keluarga menjadi ruang tidur tambahan pada malam hari; (2) Penambahan fungsi ruang jemur pada langit-langit kamar tidur keluarga sekunder; (3) Penambahan peletakan perabot berlebih pada kolong dapur; (4) Penambahan fungsi ruang tamu tambahan pada koridor; (5) Penambahan fungsi gudang pada ruang jemur; (6) Penambahan fungsi ruang cuci pada kamar mandi dan sekitarnya..

Adaptasi pada unit hunian TA 1416 juga dilakukan dengan menata layout ruang-dalam unit untuk mendapat luasan efektif, kemudian dibandingkan dengan standar antropometri manusia untuk menentukan kenyamanan gerak dalam unit hunian tersebut. Ruang yang tidak memenuhi kenyamanan gerak dalam unit hunian TA 1416, antara lain: (1) Pergerakan sirkulasi yang kurang nyaman pada ruang keluarga, kamar mandi dan sirkulasi menuju entrance kedua kamar tidur dan ruang jemur. (2) Kurang nyamannya pergerakan pada ruang jemur dan pada kamar tidur (untuk keluarga sekunder) akibat penambahan ruang jemur dikarenakan tinggi gantungan jemuran yang bertabrakan dengan skala manusia

\subsection{PENGARUH JUMLAH PENGHUNI TERHADAP KENYAMANAN GERAK ANTARUNIT HUNIAN RUSUNAWA}

Tabel di bawah ini menunjukan pemenuhan kenyamanan gerak pada setiap unit hunian yang diketahui dengan membandingkan dimensi gerak yang terjadi pada unit hunian dengan standar antropometri manusia pada umumnya. Lingkaran hijau ( ) menunju $n$ terpenuhinya kenyaman gerak pada ruang tertentu dalam unit hunian, sedangkan lingkaran merah ( ) menunjan tidak terpenuhinya kenyamanan gerak dalam ruang tertentu dalam unit hunian. 
Tabel 1. Perbandingan Kenyamanan Ruang Gerak AntarUnit Hunian Rusunawa

\begin{tabular}{|c|c|c|c|c|c|c|c|c|}
\hline Unit & $\begin{array}{c}\text { Jumlah } \\
\text { orang }\end{array}$ & $\begin{array}{c}\text { R.keluarga/ } \\
\text { tamu/ } \\
\text { makan }\end{array}$ & Dapur & $\begin{array}{c}\text { Kamar } \\
\text { tidur } \\
\text { utama }\end{array}$ & $\begin{array}{c}\text { Kamar } \\
\text { tidur anak } \\
\text { /tambahan }\end{array}$ & $\begin{array}{l}\text { Kamar } \\
\text { mandi }\end{array}$ & $\begin{array}{l}\text { Ruang } \\
\text { jemur }\end{array}$ & $\begin{array}{c}\text { Koridor } \\
\text { luar }\end{array}$ \\
\hline $\begin{array}{c}\text { TB } \\
0610\end{array}$ & 4 orang & & & & & & & \\
\hline $\begin{array}{c}\text { TB } \\
1416 \\
\end{array}$ & 4 orang & & & & & & & \\
\hline $\begin{array}{c}\text { TA } \\
0610 \\
\end{array}$ & 5 orang & & & & & & & \\
\hline $\begin{array}{c}\text { TA } \\
1318 \\
\end{array}$ & 6 orang & & & & & & & \\
\hline \begin{tabular}{|c|} 
TA \\
1406 \\
\end{tabular} & 6 orang & & & & & & & \\
\hline $\begin{array}{c}\text { TA } \\
1611\end{array}$ & 6 orang & & & & & & & \\
\hline $\begin{array}{c}\text { TB } \\
0302 \\
\end{array}$ & 7 orang & & & & & & & \\
\hline \begin{tabular}{c|} 
TB \\
0909 \\
\end{tabular} & 7 orang & & & & & & & \\
\hline $\begin{array}{c}\text { TA } \\
0615\end{array}$ & 8 orang & & & & 0 & 0 & & \\
\hline $\begin{array}{c}\text { TA } \\
1416 \\
\end{array}$ & 8 orang & & & & & & & \\
\hline
\end{tabular}

Analisis perbandingan kenyamanan gerak antarunit hunian rusunawa tersebut dapat dirangkum dalam tabel di bawah ini:

Tabel 2. Hubungan Jumlah Ketidaknyamanan Ruang Gerak dengan Jumlah Penghuni

\begin{tabular}{|c|c|l|}
\hline $\begin{array}{c}\text { Jumlah } \\
\text { Penghuni }\end{array}$ & $\begin{array}{c}\text { Ruang yang } \\
\text { tidak nyaman } \\
\text { gerak }\end{array}$ & $\begin{array}{l}\text { Keterangan Hubungan Jumlah Ketidaknyamanan Ruang } \\
\text { Gerak dengan Jumlah Penghuni }\end{array}$ \\
\hline 4 orang & $3-4$ ruang & $\begin{array}{l}\text { Standar batas ketidaknyamanan ruang. } \\
\text { 4 orang adalah jumlah ideal dalam 1 unit. }\end{array}$ \\
\hline 5 orang & 3 ruang & $\begin{array}{l}\text { Ruang yang tidak nyaman masih dalam batas wajar. } \\
\text { Artinya, unit masih bisa menampung 5 orang. }\end{array}$ \\
\hline 6 orang & $2-5$ ruang & $\begin{array}{l}\text { Ruang yang tidak nyaman masih dalam batas wajar. Namun } \\
\text { untuk beberapa kasus, dapat terjadi pengecualian. } \\
\text { Artinya, unit masih bisa menampung 6 orang. }\end{array}$ \\
\hline 7 orang & 5 ruang & $\begin{array}{l}\text { Ruang yang tidak nyaman melebihi batas standar. } \\
\text { Artinya, 7 dan 8 orang dalam 1 unit melebihi kapasitas } \\
\text { yang seharusnya ditampung. }\end{array}$ \\
\hline 8 orang & $4-5$ ruang \\
\hline
\end{tabular}

\subsubsection{ADAPTASI KEPADATAN (DENSITY) DAN KESESAKAN (CROWDING) RUANG PADA UNIT HUNIAN DALAM MENGHADAPI KETIDAKNYAMANAN RUANG GERAK}

Ketika jumlah penghuni mencapai jumlah maksimal, tercipta kepadatan (density) dan kesesakan (crowding) ruang yang menyebabkan ketidaknyamanan ruang gerak yang terjadi pada unit hunian yang ditinggali sehingga perlu dilakukan adaptasi penghuni untuk 
mengembangkan hunian tempat tinggalnya sehingga menjadi lebih layak. Adaptasi yang dilakukan oleh penghuni antara lain:

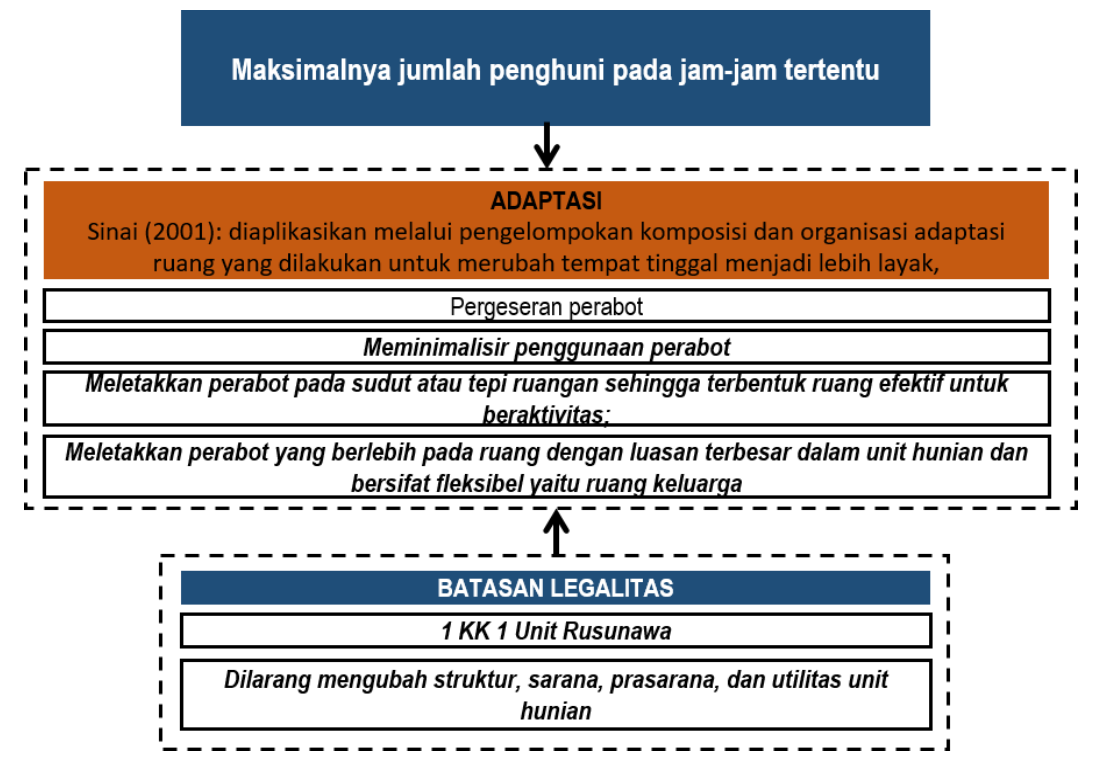

Figur 33. Skema Adaptasi yang Dilakukan Penghuni yang Disebabkan Ketidaknyamanan Ruang Gerak

Dari analisis, diketahui bahwa ketidaknyamanan gerak dalam ruang keluarga/ tamu/ makan merupakan hasil adaptasi yang dilakukan oleh penghuni unit rusunawa. Ketidaknyamanan gerak pada ruang dengan fungsi kamar tidur umumnya disebabkan oleh perletakan perabot yang mengganggu sirkulasi, sementara ketidaknyamanan gerak pada kamar mandi (ditambah fungsi ruang cuci) dan ruang jemur (ditambah fungsi gudang) umumnya disebabkan karena keterbatasan luasan yang diperuntukan untuk fungsi servis.

\subsubsection{PENYEBAB KETIDAKNYAMANAN RUANG GERAK DALAM UNIT HUNIAN}

Penyebab ketidaknyamanan ruang gerak pada beberapa ruang di unit hunian Rusunawa Jatinegara Barat, antara lain disebabkan oleh: (1) Jumlah penghuni dalam 1 unit rusunawa yang melebihi daya tampung unit rusunawa sehingga terjadi kepadatan (density) dan kesesakan (crowding) ruang dalam unit hunian rusunawa. (2) Perletakan perabot yang berlebih pada ruang - ruang tertentu dalam unit hunian rusunawa yang menggangu jalannya sirkulasi manusia dan tidak memenuhi standar minimal antopometri manusia. (3) Keterbatasan luasan unit untuk menampung fungsi-fungsi tertentu (seperti fungsi servis) yang mengakibatkan tidak terpenuhinya kenyamanan gerak pada ruang tersebut, seperti kamar mandi dan ruang jemur.

\subsection{PENGARUH JUMLAH PENGHUNI TERHADAP PERUBAHAN/ FLEKSIBILITAS FUNGSI ANTAR UNIT HUNIAN RUSUNAWA}

Tabel di bawah ini menunjukan perubahan/ fleksibilitas fungsi yang terjadi dalam unit hunian yang dibagi menjadi 3 kategori yaitu; (1) "Berfungsi sesuai fungsinya" yang diwakili dengan ikon ( Yyang artinya fungsi ruang tidak berubah dan dengan baik mendukung fungsi ruang sesuai desain asalnya; (2) "Terjadi penambahan fungsi” yang diwakili dengan ikon ( ) yang altinya fungsi ruang tersebut ditunjang dengan fungsi lain yang ditambahkan oleh penghuninya sebagai bentuk adaptabilitas ruang; (3) "Terjadi perubahan fungsi" yang diwakili oleh ikon ( ) yang artinga fungsinya telah berubah dari fungsi awal yang dimaksudkan. 
Tabel 3. Perbandingan Perubahan / Fleksibilitas Fungsi AntarUnit Hunian Rusunawa

\begin{tabular}{|c|c|c|c|c|c|c|c|c|c|c|c|c|c|c|c|}
\hline \multirow{3}{*}{\begin{tabular}{c|} 
Unit \\
Wakt
\end{tabular}} & & \multicolumn{12}{|c|}{ Ruang dalam unit hunian } & \multirow{2}{*}{\multicolumn{2}{|c|}{$\begin{array}{l}\text { Koridor } \\
\text { luar }\end{array}$}} \\
\hline & & \multicolumn{2}{|c|}{$\begin{array}{c}\text { R.keluarga/ } \\
\text { tamu } \\
\text { /makan } \\
\end{array}$} & \multicolumn{2}{|c|}{ Dapur } & \multicolumn{2}{|c|}{$\begin{array}{c}\text { Kamar } \\
\text { tidur } \\
\text { utama } \\
\end{array}$} & \multicolumn{2}{|c|}{$\begin{array}{c}\text { Kamar } \\
\text { tidur } \\
\text { anak/ } \\
\text { tambahan }\end{array}$} & \multicolumn{2}{|c|}{$\begin{array}{c}\text { Kamar } \\
\text { mandi }\end{array}$} & \multicolumn{2}{|c|}{$\begin{array}{l}\text { Ruang } \\
\text { jemur }\end{array}$} & & \\
\hline & & 粰 & C & 谊 & C & 㻤 & C & 眇 & C & 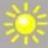 & C & 頖 & C & 㻤 & C \\
\hline $\begin{array}{c}\text { TB } \\
0610 \\
\end{array}$ & 4 & $\checkmark$ & $\checkmark$ & $\checkmark$ & $\checkmark$ & $\checkmark$ & $\checkmark$ & $\checkmark$ & $\checkmark$ & + & $\checkmark$ & + & + & $\checkmark$ & $\checkmark$ \\
\hline $\begin{array}{c}\text { TB } \\
1416\end{array}$ & 4 & + & $\geqslant$ & $\checkmark$ & $\checkmark$ & $\checkmark$ & $\checkmark$ & $\checkmark$ & $\checkmark$ & + & $\checkmark$ & + & + & $\checkmark$ & $\checkmark$ \\
\hline $\begin{array}{c}\text { TA } \\
0610\end{array}$ & 5 & $\checkmark$ & $\approx$ & $\checkmark$ & $\checkmark$ & $\checkmark$ & $\checkmark$ & $\checkmark$ & $\checkmark$ & + & + & + & + & + & + \\
\hline $\begin{array}{c}\text { TA } \\
1318 \\
\end{array}$ & 6 & $\checkmark$ & $\approx$ & + & $\checkmark$ & $\checkmark$ & $\checkmark$ & $\checkmark$ & $\checkmark$ & + & + & + & + & $\checkmark$ & $\checkmark$ \\
\hline $\begin{array}{c}\text { TA } \\
1406 \\
\end{array}$ & 6 & $\checkmark$ & $\geqslant$ & $\checkmark$ & $\checkmark$ & $\checkmark$ & $\checkmark$ & $\checkmark$ & $\checkmark$ & + & $\checkmark$ & + & + & $\checkmark$ & $\checkmark$ \\
\hline $\begin{array}{c}\text { TA } \\
1611 \\
\end{array}$ & 6 & + & $\geqslant$ & $\checkmark$ & $\checkmark$ & + & + & $\checkmark$ & $\checkmark$ & + & $\checkmark$ & + & + & + & + \\
\hline $\begin{array}{c}\text { TB } \\
0302 \\
\end{array}$ & 7 & + & 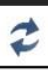 & $\checkmark$ & $\checkmark$ & $\checkmark$ & $\checkmark$ & $\checkmark$ & $\checkmark$ & + & + & + & + & $\checkmark$ & $\checkmark$ \\
\hline $\begin{array}{c}\text { TB } \\
0909\end{array}$ & 7 & + & $\approx$ & $\checkmark$ & $\checkmark$ & $\geqslant$ & $\approx$ & $\checkmark$ & $\checkmark$ & + & + & + & + & $\checkmark$ & $\checkmark$ \\
\hline $\begin{array}{c}\text { TA } \\
0615 \\
\end{array}$ & 8 & $\geqslant$ & $\approx$ & + & $\checkmark$ & $\checkmark$ & $\checkmark$ & $\checkmark$ & $\checkmark$ & + & + & + & + & + & + \\
\hline $\begin{array}{c}\text { TA } \\
1416\end{array}$ & 8 & $\checkmark$ & 2 & + & $\checkmark$ & $\checkmark$ & $\checkmark$ & + & + & + & $\checkmark$ & + & + & + & + \\
\hline
\end{tabular}

Analisis perbandingan perubahan / fleksibilitas fungsi ruang antarunit hunian rusunawa tersebut dapat dirangkum dalam tabel di bawah ini:

Tabel 4. Hubungan Perubahan/Fleksibilitas Fungsi Ruang dengan Jumlah Penghuni

\begin{tabular}{|c|c|}
\hline $\begin{array}{c}\text { Jumlah } \\
\text { Penghuni }\end{array}$ & $\begin{array}{c}\text { Keterangan Hubungan Perubahan/Fleksibilitas Fungsi Ruang dengan } \\
\text { Jumlah Penghuni yang Berada dalam Unit Hunian }\end{array}$ \\
\hline 4 orang & $\begin{array}{l}\text { Umumnya terjadi: } \\
\text { Penambahan fungsi ruang cuci dan / atau jemur pada kamar } \\
\text { mandi } \\
\text { Penambahan fungsi gudang pada ruang jemur }\end{array}$ \\
\hline 5 orang & $\begin{array}{l}\text { Umumnya terjadi: } \\
\text { Penambahan fungsi ruang cuci dan / atau jemur pada kamar } \\
\text { mandi } \\
\text { Penambahan fungsi gudang pada ruang jemur } \\
\text { Perubahan fungsi ruang keluarga menjadi ruang tidur (malam } \\
\text { hari). }\end{array}$ \\
\hline 6 orang & $\begin{array}{l}\text { Umumnya terjadi: } \\
\text { Penambahan fungsi ruang cuci dan / atau jemur pada kamar }\end{array}$ \\
\hline 7 orang & $\begin{array}{r}\text { mandi } \\
\text { Penambahan fungsi gudang pada ruang jemur } \\
\text { Perubahan fungsi ruang keluarga menjadi ruang tidur (malam } \\
\text { hari). } \\
\text { Penambahan atau perubahan fungsi sekunder pada ruang inti } \\
\text { yang bersifat privat }\end{array}$ \\
\hline
\end{tabular}




\begin{tabular}{|c|c|}
\hline 8 orang & $\begin{array}{r}\text { Umumnya terjadi: } \\
\text { Penambahan fungsi ruang cuci dan / atau jemur pada kamar } \\
\text { mandi } \\
\text { Penambahan fungsi gudang pada ruang jemur } \\
\text { Perubahan fungsi ruang keluarga menjadi ruang tidur (malam } \\
\text { hari). } \\
\text { Penambahan atau perubahan fungsi sekunder pada ruang inti } \\
\text { yang bersifat privat } \\
\text { Penambahan teritori ke koridor luar sebagai ruang efektif } \\
\text { untuk aktivitas penghuni (umumya ruang tamu tambahan) }\end{array}$ \\
\hline
\end{tabular}

\subsubsection{ADAPTASI KEPADATAN (DENSITY) DAN KESESAKAN (CROWDING) RUANG PADA UNIT HUNIAN DENGAN PERUBAHAN / FLEKSIBILITAS FUNGSI RUANG}

Ketika jumlah penghuni mencapai jumlah maksimal, tercipta kepadatan (density) dan kesesakan (crowding) ruang yang menyebabkan tidak terpenuhinya fungsi ruang pada unit hunianyang ditinggali sehingga perlu dilakukan adaptasi penghuni berupa perubahan / fleksibilitas fungsi ruang untuk mengembangkan hunian tempat tinggalnya sehingga menjadi lebih layak.

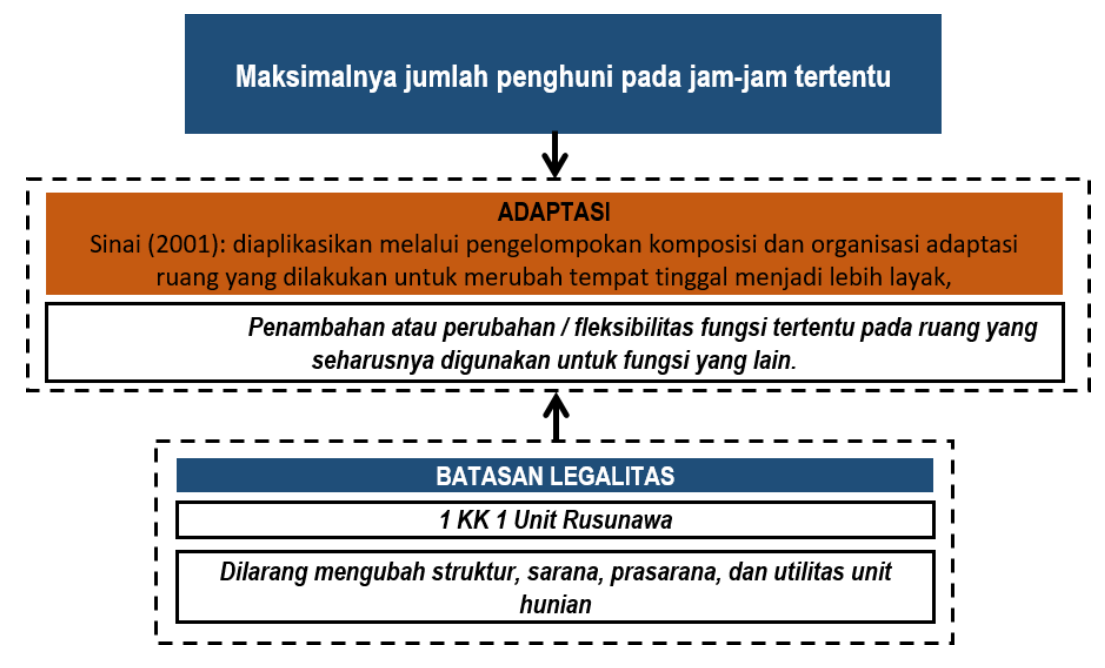

Figur 34. Skema Adaptasi yang Dilakukan Penghuni dengan Perubahan / Fleksibilitas Fungsi

\subsubsection{PENYEBAB PERUBAHAN / FLEKSIBILITAS FUNGSI PADA UNIT HUNIAN}

Beberapa penyebab perubahan dan / atau fleksibilitas fungsi pada beberapa ruang di unit hunian Rusunawa Jatinegara Barat, antara lain: (1) Keterbatasan luasan unit hunian untuk menampung fungsi-fungsi sekunder yang umumnya bersifat servis seperti ruang jemur, ruang cuci, dan gudang; (2) Keterbatasan luasan unit hunian untuk menampung fungsi pekerjaan penghuni di dalam unit huniannya sehingga harus merubah fungsi ruang yang lain menjadi ruang kerja; (3) Jumlah penghuni dalam 1 unit rusunawa umumnya melebihi kapasitas yang ada sehingga fasilitas yang disediakan oleh unit rusunawa tidak dapat menampung semua aktivitas penghuni yang ada yang menyebabkan tercipta kepadatan (density) dan kesesakan (crowding) ruang yang mendorong terjadinya adaptasi yang dilakukan penghuni yang bersifat perubahan / fleksibilitas ruang; (4) Batasan legalitas bahwa penghuni unit rusunawa hanya 
boleh menyewa 1 unit rusunawa untuk 1 kepala keluarga (yang ditentukan oleh Peraturan Gubernur Provinsi DKI Jakarta Nomor 111 Tahun 2014) yang berlaku bagi semua, tidak peduli berapapun jumlah penghuni dalam unit hunian.

\section{KESIMPULAN}

Menurut analisis telah dilakukan, dapat disimpulkan bahwa terdapat hubungan sebab akibat antara jumlah penghuni dengan perubahan / fleksibilitas fungsi ruang dan kenyamanan gerak ruang dijelaskan dalam skema di bawah ini:

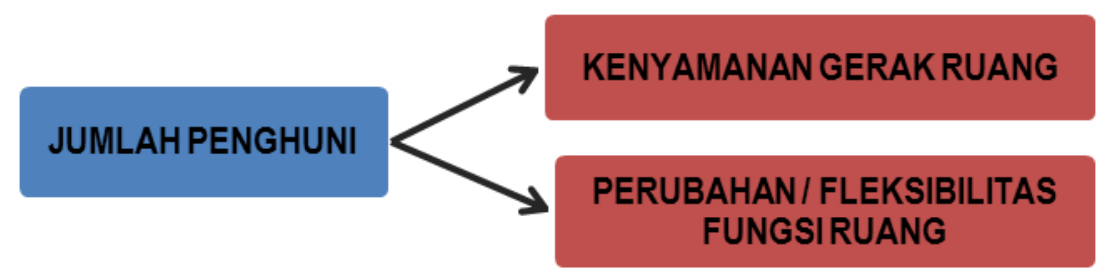

Figur 33. Hubungan Sebab Akibat Antara Jumlah Penghuni, Perubahan/Fleksibilitas Fungsi Ruang, dan Kenyamanan Gerak Ruang

Adanya pengaruh jumlah penghuni terhadap kenyamanan gerak ruang dan perubahan/ fleksibilitas fungsi ruang dipengaruhi oleh:

\section{Intensitas kegiatan penghuni di dalam unit hunian menurut periode waktu.}

Diketahui bahwa terdapat jam sibuk (peak hour) penghuni yang tinggal di dalam unit hunian yaitu pada malam hari hingga subuh (sekitar pukul 9 PM sampai 4 AM) sehingga jumlah penghuni dalam unit rusunawa mencapai jumlah maksimal. Ketika jumlah penghuni mencapai jumlah maksimal, tercipta kepadatan (density) dan kesesakan (crowding) ruang yang mendorong terjadinya ketidaknyamanan gerak dan adaptasi yang dilakukan penghuni yang bersifat perubahan / fleksibilitas ruang yang umumnya terjadi pada ruang - ruang di unit hunian, khususnya di ruang keluarga/ tamu/ makan yang luasan terbesar dalam unit hunian dan memiliki fungsi yang fleksibel.

\section{Adaptasi penghuni terhadap luasan unit rusunawa yang terbatas}

Keterbatasan luasan unit hunian menyebabkan ketidaknyamanan gerak pada beberapa ruang untuk fungsi tertentu (umumnya pada fungsi servis: pada kamar mandi yang ditambah dengan fungsi ruang cuci, dan ruang jemur yang ditambah dengan fungsi gudang). Selain itu, perletakan perabot pada luasan unit yang minim dan dihuni oleh banyak orang mengakibatkan terganggunya sirkulasi manusia yang terjadi dalam unit hunian tersebut.

Keterbatasan luasan pada unit hunian juga mendorong terjadinya perubahan atau penambahan fungsi pada ruang tertentu. Kasus yang paling sering terjadi adalah penambahan fungsi servis sekunder (seperti jemur dan cuci) dengan ruang lainnya (seperti ruang kamar mandi dan ruang keluarga).

\section{DAFTAR PUSAKA}

Baum, A., \& Paulus, P. B. (1987). Crowding. In D. Stokols \& I. Altman (Eds.), Handbook of environmental psychology (Vol. 1, pp. 533-570). New York: Academic Press.

Holahan, Charles J. (1982). Environmental Psychology. New York: McGraw-Hill. 
Indonesia. 2007. Peraturan Menteri Negara Perumahan Rakyat No 14/ PERMEN/ M/ 2007, Tentang Pengelolaan Rumah Susun Sederhana Sewa. Jakarta: Kementerian/Sekretariat Negara Republik Indonesia. [Peraturan Menteri.]

Indonesia. 2014. Peraturan Gubernur Provinsi DKI Jakarta No. 111/2014, Tentang Mekanisme Penghunian Rumah Susun Sederhana Sewa. Jakarta: Kementerian/Sekretariat Negara Republik Indonesia. [Peraturan Gubernur.]

Nawawi, Hadari \& Mimi Martini. (1994). Penelitian Terapan. Yogyakarta: Gadjah Mada

Wrightsman, Lawrence S., \& Kay Deaux. 1981. Social Psychology in the 80s. Monterel, Calif.: Brooks/ Cole.

Silas, Johan. 2000. Rumah Produktif, Pendekatan Tradisi dan Masyarakat. Surabaya: Institut Teknologi 10 November.

Sinai, I. 2001. "Moving or Improving: Housing Adjustment Choice in Kumasi, Ghana." Housing Studies. Vol. 16 (1): 97-114.

Sukmadinata, Nana Syaodih. 2007. Metode Penelitian Pendidikan. Bandung: Remaja Rosda Karya. 